\title{
Effects of feed enzymes on nutritive value of hybrid triticale x Agrotriticum kernels for broiler chickens
}

\author{
M. Fabijańska ${ }^{1}$ D. Gruszecka ${ }^{2}$, I. Kosieradzka ${ }^{1}$, A. Mieczkowska ${ }^{3}$ \\ and S. Smulikowska ${ }^{3,4}$ \\ ${ }^{1}$ Department of Animal Nutrition and Feed Science, Warsaw Agricultural University \\ Ciszewskiego 8, 02-786 Warsaw, Poland \\ ${ }^{2}$ Institute of Genetics and Plant Breeding, Lublin Agricultural University \\ Akademicka 15, 20-934 Lublin, Poland \\ ${ }^{3}$ The Kielanowski Institute of Animal Physiology and Nutrition, Polish Academy of Sciences \\ 05-110 Jablonna, Poland
}

(Received 3 January 2007; accepted 2 May 2007)

\begin{abstract}
The nutritional value of hybrid triticale x Agrotriticum (Triticum aestivum $x$ Agropyron) kernels (TW) for broiler chickens was evaluated. An experiment was carried out on 40 threeweek-old broiler chickens, kept in individual cages and allocated to 4 groups, 10 birds per group. Four experimental diets were formulated, two basal wheat- and soyabean meal-based diets, unsupplemented (B) or supplemented with a xylanase preparation (BX) and two diets composed of TW mixed in a 1:1 proportion with basal diets B or BX, the latter supplemented with a $\beta$-glucanase preparation at a rate of $1 \mathrm{~g}$ per kg of TW. Trypsin inhibitor activity in TW seeds was 1.46 $\mathrm{TUI} / \mathrm{g}$, the amino acid composition of protein was similar as triticale protein. Ileal digesta viscosity in the group fed the diet with $50 \%$ TW seeds reached $5.1 \mathrm{mPas} \cdot \mathrm{s}$ and decreased to $3.1 \mathrm{mPas} \cdot \mathrm{s}$ after xylanase and $\beta$-glucanase supplementation. The apparent protein, fat and NFE digestibility of TW seeds was 88,71 and $91 \%$, respectively; protein and fat digestibility increased after enzyme supplementation. It may be concluded that TW seeds can be a valuable component of poultry diets after xylanase and $\beta$-glucanase supplementation.
\end{abstract}

KEY WORDS: triticale, Agrotriticum, xylanase, $\beta$-glucanase, digesta viscosity, nutrient digestibility, broiler chickens

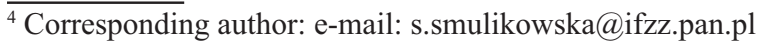




\section{INTRODUCTION}

Wheat grass (Agrotriticum $=$ Triticum aestivum $x$ Agropyron) is used as a bridging species for the indirect transfer of some useful agrobiological traits, such as resistance to pests, pathogenic agents, environmental stress factors (drought, low temperatures, salinity) from Agropyron sp. into hexaploid triticale. Arseniuk et al. (1998) proved that introgression of Stagnospora nodorum leaf and/or head resistance from Agropyron sp. into the triticale genome is feasible. However, in further stages of creative recombinative cultivation, the level of antinutrients may be the criterion for selection and evaluation of the best strains and varieties. Makarska and Gruszecka (1998) reported that in kernels of hybrid forms of triticale cv. Presto with Agrotriticum, the activity of trypsin inhibitors was intermediate or higher, while the level of alkylresorcinols was significantly higher than in the respective parental components. For young poultry, a very important trait of cereals is the viscosity of non-starch polysaccharides (NSP) in the digestive tract and the possibility of lowering the viscosity by adding enzymes. Smulikowska (1995) reported that in broiler chickens fed with triticale, digesta viscosity was higher than in chickens fed with wheat, but much lower than in chickens fed with rye. The viscosity of digesta decreased, and the metabolizable energy value increased, after supplementation of these cereals with an enzyme preparation containing xylanase and $\beta$-glucanase. The way in which the viscous NSP of cereals is inherited is not well understood and has not been studied yet in hybrids of triticale containing wheat grass genes. Also, little is known about the nutritive value of such hybrids in poultry.

The objective of this study was to evaluate the nutritional value for broiler chickens of hybrid kernels of triticale containing wheat grass genes, as well as to evaluate the effect of supplementation with xylanase and $\beta$-glucanase on the viscosity of digesta and on nutrient digestibility.

\section{MATERIAL AND METHODS}

The hybrid kernels (TW) of triticale with wheat grass (Agrotriticum $=$ Triticum aestivum x Agropyron) used were grown in 2003 at the Institute of Genetics and Plant Breeding, University of Agriculture, Lublin (Poland). Four experimental diets were formulated, two basal diets, wheat- and soyabean meal-based (Table 1), unsupplemented (B) or supplemented (BX) with $1 \mathrm{~g} / \mathrm{kg}$ of enzyme preparation Avizyme 1300 (Finnfeeds, Danisco Cultor, containing in $1 \mathrm{~g} 2500 \mathrm{U}$ endo-1,4- $\beta$-xylanase EC 3.2.1.8 and $800 \mathrm{U}$ subtilisin (protease) EC 3.4.21.62 according to the producer's declaration). The TWB diet was composed of TW mixed in a 1:1 proportion on DM basis with basal diet $\mathrm{B}$, and the TWBX diet was composed 
of TW mixed with $1 \mathrm{~g} / \mathrm{kg}$ of Avizyme 1200 (Finnfeeds, Danisco Cultor, containing per g $100 \mathrm{U}$ endo-1,3(4) $\beta$-glucanase EC 3.2.1.6; $2500 \mathrm{U}$ endo-1,4- $\beta$-xylanase EC 3.2.1.8; $800 \mathrm{U}$ subtilisin (protease) EC 3.4.21.62 according to the producer's declaration) and with basal diet BX in a 1:1 proportion. All diets were cold pelleted on a CL-2 CPM Laboratory Pellet Mill.

Table 1. Composition of basal diets, $\mathrm{g} / \mathrm{kg}$

\begin{tabular}{|c|c|c|}
\hline Components & Basal (B) & Basal + xylanase $(\mathrm{BX})$ \\
\hline Wheat cv. Corveta & 353.8 & 352.8 \\
\hline Soyabean meal & 380.6 & 380.6 \\
\hline Maize & 200.0 & 200.0 \\
\hline Limestone & 3.4 & 3.4 \\
\hline Dicalcium phosphate & 18.0 & 18.0 \\
\hline Rape seed oil & 30.0 & 30.0 \\
\hline Vitamin-mineral premix ${ }^{1}$ & 10.0 & 10.0 \\
\hline L-lysine $(78 \%)$ & 1.0 & 1.0 \\
\hline DL-methionine (98\%) & 0.2 & 0.2 \\
\hline $\mathrm{NaCl}$ & 3.0 & 3.0 \\
\hline Enzyme preparation $^{2}$ & - & 1.0 \\
\hline
\end{tabular}

${ }^{1}$ supplied per kg diet, IU: vit. A 12000; vit. $\mathrm{D}_{3} 2500$; mg: vit. E 35; vit. $\mathrm{B}_{1} 2$; vit. $\mathrm{B}_{2} 7$; biotin 0.06 ; vit. $\mathrm{B}_{6} 4$; vit. $\mathrm{B}_{12} 0.02$; vit. $\mathrm{K} 3$; niacine 30; folic acid 1; Ca pantothenate 12; choline 300; Mn 70; Zn 50; Co 0.2; Se 0.1; Cu 15; Fe 40; I 0.5; coccidiostatic (Semduramycin) 25; Avilamycin 8; Barox Dry 10; g: DL-methionine 1, Ca 2.85

${ }^{2}$ Avizyme 1300

The digestibility trial was performed on 40 three-week-old broiler females with an average body weight of $940 \mathrm{~g}$. The chickens were fed with a standard starter diet until the beginning of the experiment. The experiment was conducted in compliance with European Union regulations concerning the protection of experimental animals. The local ethics committee approved the study protocol.

On day 22 of life the birds were randomly allocated to 4 groups, 10 birds per group and were given $90 \mathrm{~g} / \mathrm{bird} /$ day of the respective diets, in three meals.

After two days of preliminary feeding the birds were fasted for $14 \mathrm{~h}$, then given the same diets for 4 days and again fasted for $14 \mathrm{~h}$. Feed intake was measured, and during $96 \mathrm{~h}$ excreta were quantitatively collected, frozen and kept at $-18^{\circ} \mathrm{C}$ for further analysis. Then chickens were offered the same diets ad libitum until they were sacrificed on the next day, the abdominal cavity was opened and the contents of the jejunum, ileum and caeca were collected. Digesta from 2 birds were pooled for $\mathrm{pH}$ and viscosity measurement.

Digesta from caeca were mixed with deionized water $(1: 1 \mathrm{w} / \mathrm{w})$ and their $\mathrm{pH}$ was immediately measured with a digital $\mathrm{pH}-$ meter (WTW $\mathrm{pH} / 340$, Germany) using pH standard WTW D-82362 Weilheim (model STP4) at room temperature. Digesta 
from the jejunum and ileum as well as diluted caecal digesta were centrifuged at $10,000 \mathrm{~g}$ for 10 min using a Beckman centrifuge (model J2-21 with J-20 rotor) at $4^{\circ} \mathrm{C}$ and the viscosity of the supernatant $(0.5 \mathrm{ml}$ aliquot $)$ was immediately measured at $40^{\circ} \mathrm{C}$ with the use of a Brookfield Digital cone/plate viscometer (model LVDV II + , Brookfield Engineering Laboratories, Stoughton, MA, USA). Readings were expressed in centipoise $(1 \mathrm{cP}=1 \mathrm{MPa} \cdot \mathrm{s})$. The in vitro viscosity in wheat and $\mathrm{TW}$ seeds was measured as follows: finely ground seeds were mixed 10:1 (w/w) with distilled water or $0.1 \mathrm{M} \mathrm{KCl} / \mathrm{HCl}$ buffer $(\mathrm{pH} 1.5)$, extracted for $1 \mathrm{~h}$ at $25^{\circ} \mathrm{C}$, centrifuged at $4000 \mathrm{~g}$ for $10 \mathrm{~min}$ and the viscosity of supernatants was measured with a Brookfield Viscometer (Model LVDV II + ).

In TW seeds, diets, and excreta, the content of dry matter, ash, crude fat, crude fibre and total $\mathrm{N}$ was measured according to AOAC (1990), N faecal in excreta according to Ekman et al. (1949). Trypsin inhibitor activity was determined according to Kakade et al. (1974). Amino acid analysis was performed with a Beckman 6300 high pressure amino acid analyser, using modified procedures described by Buraczewska and Buraczewski (1984). Apparent protein and fat digestibility and nitrogen and organic matter retention in TW seeds were calculated by the difference method as described by Smulikowska et al. (2006).

Statistical analysis was carried out with one-way analysis of variance (ANOVA) and Duncan's multiple range test, using the Statgraphics ${ }^{\circledR}$ ver. 5.1 software package.

\section{RESULTS}

Chemical composition of TW seeds is shown in Table 2 . The in vitro viscosity of water as well as acid extract of TW seeds was $1.00 \mathrm{mPas} \cdot \mathrm{s}$. The respective in vitro viscosity values for wheat $\mathrm{cv}$. Corveta used in the control diet were 0.83 and 0.87 $\mathrm{mPas} \cdot \mathrm{s}$. Trypsin inhibitor activity in TW seeds was $1.46 \mathrm{TUI} / \mathrm{g}$.

The coefficient of fat digestibility was significantly lower in chickens fed the $\mathrm{BX}$ diet in comparison with the group fed diet $\mathrm{B}$, and was lowest $(\mathrm{P}<0.01)$ in chickens fed diet TWB. In the group fed diet TWBX, fat digestibility was comparable to that in group BX. Apparent protein digestibility was significantly higher $(\mathrm{P}<0.01)$ in group TWBX in comparison with other groups, while a significant difference in nitrogen retention was found only between groups BX and TWBX. Organic matter retention was highest in group TWBX, followed $(\mathrm{P}<0.01)$ by group TWB (Table 3$)$.

The digesta viscosity in group BX was only numerically lower than in group $\mathrm{B}$, while the viscosity of jejunal and ileal digesta in chickens fed the TWB diet was significantly higher $(\mathrm{P}<0.01)$ in comparison with birds fed diets $\mathrm{B}$ and $\mathrm{BX}$. In birds fed diet TWBX, jejunal digesta viscosity was numerically, and ileal digesta 
Table 2. Chemical composition and amino acid content of hybrid kernels triticale $\times$ Agrotriticum (TW)

\begin{tabular}{lrlr}
\hline \multicolumn{2}{c}{ Chemical composition, g/kg DM } & & Amino acids, g/16 g N \\
\hline Crude protein $(\mathrm{N} \times 6.25)$ & 112.7 & Lysine & 3.60 \\
Crude fat & 14.3 & Methionine & 1.72 \\
Crude ash & 19.5 & Cystine & 2.49 \\
Crude fibre & 28.4 & Threonine & 3.16 \\
N-free extractives & 825.1 & Tryptophan & 0.94 \\
Trypsin inhibitor activity, TUI/g* & 1.46 & Valine & 4.60 \\
& & Isoleucine & 3.74 \\
& & Leucine & 6.74 \\
& & Phenylalanine & 4.60 \\
& & Tyrosine & 3.03 \\
& & Histidine & 2.39 \\
& & Arginine & 5.45 \\
& & Aspartic acid & 6.29 \\
& & Glutamic acid & 27.25 \\
& & Serine & 4.78 \\
& & Proline & 9.50 \\
& & Glycine & 4.32 \\
& & Alanine & 3.78 \\
\hline
\end{tabular}

* TUI - mg of bovine trypsin inhibited by inhibitor present in $1 \mathrm{~g}$ of grain

Table 3. Results of balance experiment, viscosity of digesta $(\mathrm{mPa} \cdot \mathrm{s})$ and $\mathrm{pH}$ of caecal digesta

\begin{tabular}{|c|c|c|c|c|c|}
\hline \multirow[t]{2}{*}{ Item } & \multicolumn{4}{|c|}{ Dietary treatment } & \multirow[b]{2}{*}{ SEM } \\
\hline & $\begin{array}{l}\text { Basal } \\
\text { diet } \\
\text { (B) }\end{array}$ & $\begin{array}{l}\text { B with } \\
\text { xylanase } \\
(\mathrm{BX})\end{array}$ & $\begin{array}{c}\mathrm{TW}+\mathrm{B} \\
1: 1(\mathrm{TWB})\end{array}$ & $\begin{array}{l}\text { TW with xylanase } \\
\text { and } \beta \text {-glucanase }+ \\
\text { BX 1:1 (TWBX) }\end{array}$ & \\
\hline Apparent protein digestibility, $\%$ & $87.7^{\mathrm{A}}$ & $88.8^{\mathrm{A}}$ & $88.1^{\mathrm{A}}$ & $90.6^{\mathrm{B}}$ & 0.39 \\
\hline Apparent fat digestibility, $\%$ & $88.1^{\mathrm{A}}$ & $84.8^{\mathrm{B}}$ & $79.5^{\mathrm{C}}$ & $84.0^{\mathrm{B}}$ & 0.63 \\
\hline $\mathrm{N}$ retention, $\%$ & $56.3^{\mathrm{AB}}$ & $53.5^{\mathrm{A}}$ & $55.7^{\mathrm{AB}}$ & $57.7^{\mathrm{B}}$ & 0.73 \\
\hline Organic matter retention, $\%$ & $75.4^{\mathrm{A}}$ & $74.2^{\mathrm{A}}$ & $79.2^{\mathrm{B}}$ & $81.1^{\mathrm{C}}$ & 0.37 \\
\hline \multicolumn{6}{|l|}{ Digesta viscosity, $\mathrm{mPas} \cdot \mathrm{s}$} \\
\hline jejunum & $1.36^{\mathrm{A}}$ & $1.27^{\mathrm{A}}$ & $2.53^{\mathrm{B}}$ & $2.10^{\mathrm{B}}$ & 0.14 \\
\hline ileum & $1.84^{\mathrm{a}}$ & $1.76^{\mathrm{a}}$ & $5.10^{\mathrm{c}}$ & $3.11^{\mathrm{b}}$ & 0.31 \\
\hline caeca* & 1.77 & 1.47 & 1.30 & 1.52 & 0.18 \\
\hline Caecal digesta*, $\mathrm{pH}$ & 6.76 & 6.81 & 6.71 & 6.46 & 0.13 \\
\hline
\end{tabular}

TW - triticale x Agrotriticum seeds; * mixed 1:1 w/w with distilled water; ${ }^{\text {a,b, }, \mathrm{A}, \mathrm{B}}$ means in rows with different superscripts were significantly different at ${ }^{\text {ab }} \mathrm{P}<0.05 ;{ }^{\mathrm{AB}} \mathrm{P}<0.01$

viscosity, significantly $(\mathrm{P}<0.05)$ lower than in birds fed diet TWB, however, both were significantly $(\mathrm{P}<0.05)$ higher than in groups $\mathrm{B}$ and $\mathrm{BX}($ Table 3$)$.

Apparent protein and fat digestibility and nitrogen and organic matter retention coefficients in supplemented TW seeds calculated by the difference 
method were significantly $(\mathrm{P}<0.05 ; \mathrm{P}<0.01)$ higher in comparison with unsupplemented seeds (Table 4).

Table 4. Apparent protein and fat digestibility and nitrogen and organic matter retention of hybrid kernels triticale $\times$ Agrotriticum $(\mathrm{TW})$

\begin{tabular}{lccc}
\hline Item & $\begin{array}{c}\text { TW seeds } \\
\text { unsupplemented }\end{array}$ & $\begin{array}{c}\text { TW seeds + xylanase } \\
\text { and } \beta \text {-glucanase }\end{array}$ & SEM \\
\hline Apparent protein digestibility, \% & $88.5^{\mathrm{a}}$ & $92.4^{\mathrm{b}}$ & 1.07 \\
Apparent fat digestibility, \% & $70.9^{\mathrm{A}}$ & $83.5^{\mathrm{B}}$ & 0.94 \\
N retention, \% & $55.0^{\mathrm{A}}$ & $63.1^{\mathrm{B}}$ & 1.51 \\
Organic matter retention, \% & $82.9^{\mathrm{A}}$ & $88.3^{\mathrm{B}}$ & 0.94 \\
NFE digestibility, \% & 90.8 & $\mathrm{nc}$ & \\
\hline
\end{tabular}

$\overline{\mathrm{a}, \mathrm{b}, \mathrm{A}, \mathrm{B}}$ means in rows with different superscripts were significantly different at: ${ }^{\mathrm{a}, \mathrm{b}} \mathrm{P}<0.05 ;{ }^{\mathrm{A}, \mathrm{B}} \mathrm{P}<0.0$; nc - not calculated

\section{DISCUSSION}

The amino acid composition of hybrid kernels of triticale with wheat grass did not differ distinctly from the composition of triticale protein (Fickler et al., 2001). Trypsin inhibitor activity was comparable to the values reported previously by Makarska and Gruszecka (1998). The apparent digestibilities of crude protein, crude fat and NFE calculated for unsupplemented TW seeds were a little higher than values reported for triticale in the European Table (1989). The soluble nonstarch polysaccharides (NSP) present in cereals such as rye, barley, triticale and wheat (mainly arabinoxylans and $\beta$-glucans) impair digestion and absorption, the most affected is the digestion and absorption of fat. The detrimental effect of NSP is associated with their ability to increase digesta viscosity and to interact with the microflora of the gut. By cleaving the viscous NSP polymers, added enzymes can lower digesta viscosity, largely eliminating their anti-nutritional properties (Choct, 2006).

In the present study the in vitro and in vivo viscosity measurements indicated that the NSP of wheat used in the basal diet were not very viscous. The decrease of digesta viscosity in chickens fed the basal diet supplemented with xylanase was very small, however, the fat digestibility was negatively affected in comparison with the unsupplemented group. It can be hypothesized that in group BX, wheat NSP were partially depolimerized by added enzymes and could be utilized by the microflora in the distal parts of the chickens' gut. The more numerous microflora could deconjugate bile acids, which are necessary for proper fat digestion, more intensively.

The viscosity generated in chicken digesta by hybrid kernels of triticale with wheat grass can be compared to the viscosity of triticale evaluated previously in our 
laboratory. We found that the ileal digesta viscosity in chickens fed triticale averaged $4.32 \mathrm{mPas} \cdot \mathrm{s}$ and was about two-fold higher than in chickens fed wheat. It decreased by about $40 \%$ due to xylanase and $\beta$-glucanase supplementation (Smulikowska, 1995). In the present study in chickens fed the diet containing 50\% hybrid kernels of triticale with wheat grass and supplemented with xylanase and $\beta$-glucanase, the digesta viscosity decreased by $17 \%$ in the jejunum and by $40 \%$ in the ileum in comparison with chickens fed with unsupplemented diet. The decrease in digesta viscosity was accompanied by an increase in nutrient digestibility.

It can be concluded that seeds of triticale containing wheat grass genes can be a valuable component of poultry diets after xylanase and $\beta$-glucanase supplementation.

\section{REFERENCES}

AOAC, 1990. Official Methods of Analysis, Association of Official Analytical Chemists. $15^{\text {th }}$ Edition. Washington, DC

Arseniuk E., Gruszecka D., Tarkowski Cz., 1998. Analysis of Stagnospora nodorum blotch resistance in hybrids of triticale, wheat, rye, Aegilops sp., Agrotriticum sp. and Dasypyrum sp. In: Proceedings of 4th International Triticale Symposium. Red Deer, Alberta (Canada), Vol. 1, 303-311

Buraczewska L., Buraczewski S., 1984. A note on determination of methionine and tryptophan. In: Proceedings of 6th International Symposium on Amino Acids, Serock (Poland), pp. 47-50

Choct M., 2006. Enzymes for the feed industry: past, present and future. World Poultry Sci. J. 62, 5-15

Ekman P., Emanuelson H., Fransson A., 1949. The digestibility of protein in poultry. KGL Lantbruks.Hogskol. Ann. 1, 749

European Table of Energy Values for Poultry Feedstuffs, 1989. Working Group No. 2, Nutrition. WPSA, Beekbergen (The Netherlands)

Fickler J., Fontaine J., Heimbeck W., 2001. The Amino Acid Composition of Feedstuffs. Degussa Feed Additives

Kakade M.L., Rackis J.J., Mac Ghee J.E., Puski C., 1974. Determination of trypsin activity of soy products: A collaborative analysis of an improved procedure. Cereal Chem. 51, 376-382

Makarska E., Gruszecka D., 1998. Antitrypsin activity and level of alkylresorcinols in hybrid kernels of X Triticosecale Wittmack with Agrotriticum and in parental forms. Pol. J. Food Nutr. Sci. 7/48, $431-435$

Smulikowska S., 1995. Effect of age and enzyme supplementation on metabolizable energy of rye, triticale and wheat for poultry. In: Proceedings of 10th European Symposium on Poultry Nutrition, Antalya (Turkey), pp. 258-259

Smulikowska S., Mieczkowska A., Czerwiński J., Weremko D., Nguyen C.V., 2006. Effects of exogenous phytase in chickens fed diets with differently processed rapeseed expeller cakes. J. Anim. Feed Sci. 15, 237-252

Statgraphics ${ }^{\circledR}$ ver. 5.1., 1994-2001. Statistical Graphic System by Statistical Graphic Corp. (USA) 